\title{
RESPON PERTUMBUHAN TANAMAN SELADA (Lactuca Sativa L) TERHADAP VOLUME AIR DAN KONSENTRASI LARUTAN NUTRISI GOOD-PLANT SECARA HIDROPONIK
}

\section{Plant Growth Response Lettuce (Lactuca sativa L) Against Water Volume and Concentration Solution Good-Plant Nutrition By Hydroponics}

\author{
Nuryulsen Safridar ${ }^{(1)}$, Sri Handayani ${ }^{(2)}$ \\ ${ }^{1,2}$ Program Studi Agroteknologi Universitas Jabal Ghafur \\ Email : nuryulsen@unigha.ac.id
}

\begin{abstract}
ABSTRAK
Penelitian ini bertujuan untuk mengetahui volume air dan konsentrasi larutan nutrisi good plant dan yang tepat terhadap pertumbuhan tanaman selada (lactuca sativa L). Penelitian ini telah dilaksanakan dikebun percobaan Fakultas Pertanian Universitas Jabal Ghafur Sigli. Berlangsung dari bulan Februari sampai dengan April 2017. Penelitian ini menggunakan sistim hidroponik rakit apung. Penelitian menggunakan Rancangan Acak Lengkap (RAL) pola faktorial yaitu faktor volume air dan faktor konsentrasi hara good-plant. Perlakuan volume air (V) terdiri dari 3 taraf yaitu $\left(\mathrm{V}_{1}\right) 4$ liter air, $\left(\mathrm{V}_{2}\right) 8$ liter air dan $\left(\mathrm{V}_{3}\right) 12$ liter air. Perlakuan konsentrasi nutrisi good-plant $(\mathrm{N})$ terdiri dari 3 taraf yaitu $\left(\mathrm{N}_{1}\right) 600 \mathrm{ppm},\left(\mathrm{N}_{2}\right) 800 \mathrm{ppm}$ dan $\left(\mathrm{N}_{3}\right)$ 1000 ppm, dengan 3 ulangan sehingga secara keseluruhan dipeloreh 27 satuan percobaan. Volume air berpengaruh sangat nyata terhadap tinggi tanaman dan panjang daun umur 10, 20 dan 30 HST, jumlah daun umur 20 dan 30 HST, berat brangkasan basah umur 30 HST, berpengaruh nyata terhadap jumlah daun umur 10 HST. Nutrisi good-plant berpengaruh sangat nyata terhadap tinggi tanaman umur 20 dan 30 HST, jumlah daun dan panjang daun umur 30 HST, berpengaruh nyata terhadap tinggi tanaman umur $10 \mathrm{HST}$, panjang daun umur $20 \mathrm{HST}$, berat brangkasan basah umur 30 HST.
\end{abstract}

Kata kunci : selada, hidroponik, volume air dan konsentrasi nutrisi good-plant

\begin{abstract}
This study aims to determine the volume of water and the concentration of the nutrient solution and the right good plant to plant growth of lettuce (lactuca sativa L). This research has been carried out in the garden experiment Jabal Ghafur Faculty of Agriculture, University of Sigli. Runs from February to April 2017. This study used a raft floating hydroponics system. Research using completely randomized design (CRD) factorial pattern that is factor of the volume of water and nutrient concentration factor of good-plant. Treatment of the water volume (V) consists of three levels ie (V1) 4 liters of water, (V2) 8 liters of water and (V3) 12 liters of water. Good treatment-plant nutrient concentrations (N) consists of three levels ie (N1) $600 \mathrm{ppm}(\mathrm{N} 2)$ of $800 \mathrm{ppm}$ and (N3) $1000 \mathrm{ppm}$, with three replications so overall dipeloreh 27 experimental unit. The volume of water very significant effect on plant height and leaf length aged 10, 20 and 30 days after planting, leaf number aged 20 and 30 days after planting, heavy wet stover age $30 \mathrm{HST}$, significantly affect the amount of leaf age 10 HST. Good-plant nutrients
\end{abstract}


very significant effect on plant height ages of 20 and 30 days after planting, leaf number and length of leaf age $30 \mathrm{HST}$, significant effect on plant height HST age 10, age $20 \mathrm{HST}$ leaf length, weight of wet age 30 HST stover.

Keywords: lettuce, hydroponics, water volume and concentration of good-plant nutrients

\section{PENDAHULUAN}

\section{Latar Belakang}

Selada (lactuca sativa L) merupakan sayuran daun yang berasal dari Negara beriklim sedang. Menurut sejarahnya, tanaman ini telah di budidayakan sekitar 2500 tahun yang lalu. Tanaman selada berasal dari kawasan Amerika. Hal ini di buktikan oleh Cristoper Columbus pada tahun 1493 yang menemukan tanaman selada di daerah Hemisphere bagian barat dan Bahamas (H.mas' ud, 2009).

Hidroponik merupakan metode bercocok tanam tanpa menggunakan tanah. Hidroponik berasal dari kata hydroponick, bahasa Yunani. Kata tersebut merupakan gabungan dari dua kata yaitu hydro yang berarti air dan ponos yang berarti berkerja jadi hidroponik artinya pengerjaan air atau bekerja dengan air. Biasanya media yang di gunakan adalah arang sekam, pasir, zeolit, rockwoll, gambut dan sabut kelapa (Prihmantoro. 2005).

Pada teknik budidaya hidroponik memiliki keuntungan bagi orang yang tinggal di rumah dengan halaman yang sempit dan juga mahasiswa yang bertempat tinggal di kos. Karena dengan menggunakan teknik hidroponik ini, orang-orang dapat menikmati sayuran dari hasil berkebun sendiri. Akan tetapi pada teknik ini sistem pengairan harus teratur karena berpengaruh pada pertumbuhan tanaman.

Dalam budidaya tanaman selada hidroponik di butuhkan nutrisi sebesar 560 sampai 840 ppm atau dengan rekomendasi sebesar 800 ppm. Berdasarkan paparan diatas, maka penulis mencoba membuat penelitian dengan tajuk Respon Pertumbuhan Tanaman Selada (lactuca sativa.L) Terhadap Volume Air Dan Konsentrasi Larutan Nutrisi Goodplant Secara Hidroponik.

\section{Tujuan Penelitian}

Adapun tujuan dari penelitian ini adalah untuk mengetahui volume air dan konsentrasi larutan nutrisi good plant dan yang tepat terhadap pertumbuhan tanaman selada (lactuca sativa L).

\section{Hipotesis}

1. Di duga volume air berpengaruh terhadap pertumbuhan tanaman selada

2. Di duga konsentrasi larutan nutrisi goold plant berpengaruh terhadap pertumbuhan tanaman selada.

\section{METODELOGI PENELITIAN}

Penelitian ini telah dilaksanakan dikebun percobaan Fakultas Pertanian Universitas Jabal Ghafur Sigli. Berlangsung dari bulan Februari sampai dengan April 2017.

Bahan yang di gunakan dalam penelitian ini adalah nutrisi goold plant, $\mathrm{PH}$ up dan $\mathrm{PH}$ down, air, benih, rockwol dan kain flannel.

Alat yang di gunakan yaitu $\mathrm{pH}$ meter, TDS meter alat untuk mengukur kadar ppm pada nutrisi hidroponik dan suhu air, solder, net pot, papan infomasi, camera, alat tulis, mulsa plastik, kotak stereofoem ukuran $60 \mathrm{x}$ $40 \mathrm{~cm}$.

Penelitian ini menggunakan sistim hidroponik rakit apung. Penelitian menggunakan Rancangan Acak Lengkap (RAL) pola faktorial, ada dua faktor yang diteliti yaitu faktor volume air (V) terdiri dari 3 taraf dan faktor konsentrasi hara good-plant (N) terdiri dari 3 taraf yaitu :

Faktor volume air (V), terdiri diri 3 yaitu :

$\mathrm{V}_{1}=$ Volume air 4 liter

$\mathrm{V}_{2}=$ Volume air 8 liter

$\mathrm{V}_{3}=$ Volume air 12 liter

Faktor konsentrasi nutrisi good-plant (N), terdiri dari 3 taraf, yaitu: 
$\mathrm{N}_{1}=600 \mathrm{ppm}$

$\mathrm{N}_{2}=800 \mathrm{ppm}$

$\mathrm{N}_{3}=1000 \mathrm{ppm}$

Dengan demikian terdapat 9 kombinasi perlakuan dengan 3 ulangan sehingga secara keseluruhan diperoleh 27 satuan percobaan.

Model matematika yang akan digunakan adalah sebagai berikut:

\begin{tabular}{|c|c|}
\hline $\begin{array}{l}\mathbf{Y}_{\mathbf{i j k}=} \\
\text { Keteran }\end{array}$ & $\mu+\mathbf{K k}+\mathbf{V}_{\mathbf{i}}+\mathbf{N}_{\mathbf{j}}+(\mathbf{V N})_{\mathbf{i j}}+\varepsilon \mathbf{i j k}$ \\
\hline Yijk & $\begin{aligned} &= \text { Hasil pengamatan dari faktor } \\
& \text { volume air (V) pada taraf ke-j } \\
& \text { dan konsentrasi nutrisi }(\mathrm{N}) \\
& \text { pada taraf } \\
& \text { kelompok ke-i. }\end{aligned}$ \\
\hline $\begin{array}{l}\mu \\
\text { umum }\end{array}$ & $=$ Nilai \\
\hline $\mathrm{Kk}$ & $\begin{aligned} & \text { pengamatan. } \\
= & \text { Nilai pengamatan pengaruh } \\
& \text { kelompok ke-k. }\end{aligned}$ \\
\hline $\mathrm{Vi}$ & $\begin{aligned}= & \text { Nilai pengamatan pengaruh } \\
& \text { volume air pada taraf ke-i }\end{aligned}$ \\
\hline $\mathrm{Nj}$ & $\begin{array}{l}=\text { Nilai pengamatan pengaruh } \\
\text { konsentrasi nutrisi pada taraf } \\
\text { ke-j }\end{array}$ \\
\hline$(\mathrm{VN}) \mathrm{ij}$ & $\begin{array}{l}=\text { Nilai pengamatan interaksi } \\
\text { volume air pada taraf ke-i dan } \\
\text { konsentrasi nutrisi pada taraf } \\
\text { ke-j }\end{array}$ \\
\hline$\varepsilon \mathrm{ijk}$ & $=$ pengaruh acak percobaan \\
\hline
\end{tabular}

kelompok percobaan ke-k yang memperoleh kombinasi perlakuan jenis pada taraf ke-i dan dosis nutrisi pada taraf kej.

Untuk mengetahui pengaruh masingmasing faktor perlakuan serta interaksinya terhadap beberapa parameter pertumbuhan tanaman selada dilakukan analisis ragam (Uji Fisher) dan dilanjutkan dengan Uji Beda Nyata Jujur (BNJ) pada level 5\%.

\section{Pelaksanaan Penelitian}

Penelitian ini menggunakan metode wick sitem, teknik ini memanfaatkan gaya kapilaritas pada sumbu atau kain flanel untuk mengantarkan air dan nutrisi ke akar tanaman sehingga akar tanaman dapat menyerap usur hara yang di sediakan.

\section{Persiapan Lahan dan Pembuatan Plot}

Persiapan lahan dalam penelitian ini yaitu dengan cara pembersihan, pembuatan screen house, pembuatan rak dan membuat plot percobaan dari sterofoem kotak buah dengan ukuran $60 \mathrm{~cm}$ x $40 \mathrm{~cm}$ sebayak 27 plot untuk 9 perlakuan dengan $3 \mathrm{x}$ ulangan.

\section{Pembuatan Screen Hause}

Screen hause di buat dengan cara membuat rak dari bambu dan di lanjutkan dengan menambah atap dari plastik putih. Screen hause bertujuan untuk menghindari terkena hujan dan matahari secara langsung sehingga menghindari bertambahnya air nutrisi saat hujan.

\section{Persiapan Benih}

Benih yang akan ditanam harus melalui pembibitan terlebih dahulu selama 15 hari. Benih di tanam pada media rokwol yang telah di basahi dan lubangi dengan alat pelubang dengan kedalaman $1 \mathrm{~cm}$ jarak antar lubang $2 \mathrm{~cm}$ x $2 \mathrm{~cm}$ secara bergaris.

\section{Penanaman}

Penanaman dilakukan apabila bibit sudah berumur 18 hari dan dipilih yang berdaun 4 dengan cara memotong rockwol dengan searah serat agar akar tanaman tidak terganggu kemudian masukkan ke netpot yang telah di siapkan dengan kain flanel dan masukkan ke bak penampung atau sterofoam dengan jumlah 6 tanaman per bak penampung, dengan jarak antar tanaman 20 $\mathrm{cm}$ x $20 \mathrm{~cm}$ dan jarak jarak dari pinggir stereofoem adalah $10 \mathrm{~cm}$.

\section{Pemberian Nutrisi}

Nutrisi diberikan dengan cara memasukkan nutrisi yang telah di siapkan ke dalam bak penampung dengan takaran menurut ppm masing-masing perlakuan dan di cek dengan cara menggunakan tds meter. Sebelum memasukkan nutrisi perlu di lakukan pengecekan $\mathrm{pH}$ air menggunakan $\mathrm{pH}$ meter. Penambahan nutrisi di lakukan 3 hari sekali saat volume air dan ppm nutrisi berkurang. 


\section{Pemeliharaan}

Pemeliharaan tanaman selada secara hidroponik meliputi penyulaman, mengukur konsentrasi nutrisi, mengukur ph, mengukur suhu air, dan mengendalikan hama dan penyakit.

Benih yang tidak tumbuh segera disulam. Penyulaman dilakukan pada saat tanaman berumur 1 minggu setelah pemindahan bibit, mengukur konsentrasi nutrisi dengan tds meter apabila tidak sesuai dengan perlakuan maka perlu adanya penambahan nutris, konsentrasi nutrisi di cek setiap hari mulai dari umur pindah bibit, Mengecek $\mathrm{pH}$ dengan menggunakan $\mathrm{pH}$ meter, mengukur suhu air nutrisi, Pengendalian hama dan penyakit dilakukan bila tanaman pada kondisi serangan sudah diambang ekonomi yaitu dengan cara membuang tanaman yang terkena penyakit dan menggunakan pestisida nabati dari daun sirsak.

\section{Pengamatan}

Parameter yang diamati terdiri dari :

\section{Tinggi Tanaman.}

Tinggi tanaman diukur pada umur 10, 20 dan 30 HST dalam satuan $\mathrm{cm}$. Di ukur dari ujung akar sampai ujung daun atas.

2. Jumlah Daun

Jumlah daun per tanaman dihitung pada umur 10, 20 dan 30 HST.

3. Panjang Daun

Panjang daun di ukur pada umur 10, 20 dan 30 HST dalam satuan $\mathrm{cm}$. Di ukur dari pangkal daun sampai ke ujung daun.

4. Berat Brangkasan Basah

Berat brangkasan basah di ukur dengan cara menimbang tanaman setelah panen.

\section{HASIL DAN PEMBAHASAN}

\section{A.Volume Air \\ Tinggi Tanaman}

Hasil analisis ragam menunjukkan bahwa, volume air berpengaruh sangat nyata terhadap tinggi tanaman selada umur 10, 20 dan 30 HST. Rata-rata tinggi tanaman selada umur 10, 20 dan 30 HST akibat volume air dapat dilihat pada Tabel 1.
Tabel 1. Rata-Rata Tinggi Tanaman Selada Umur 10, 20 dan 30 HST Akibat Volume $\underline{\text { Air }}$

\begin{tabular}{cccc}
\hline Volume Air (V) & \multicolumn{3}{c}{ Tinggi Tanaman $(\mathrm{cm})$} \\
\cline { 2 - 4 } & $10 \mathrm{HST}$ & $20 \mathrm{HST}$ & $30 \mathrm{HST}$ \\
\hline $\mathrm{V}_{1}$ & $5.58 \mathrm{a}$ & $8.70 \mathrm{a}$ & $12.63 \mathrm{a}$ \\
$\mathrm{V}_{2}$ & $6.79 \mathrm{~b}$ & $12.11 \mathrm{~b}$ & $18.06 \mathrm{~b}$ \\
$\mathrm{~V}_{3}$ & $7.01 \mathrm{~b}$ & $12.47 \mathrm{~b}$ & $19.61 \mathrm{c}$ \\
\hline BNJ & 0.72 & 1.14 & 1.43 \\
\hline
\end{tabular}

Keterangan : Angka yang diikuti huruf yang sama dalam kolom yang sama menunjukkan tidak berbeda nyata pada uji BNJ 5\%

Dari Tabel 1 dapat dijelaskan bahwa, rata-rata tinggi tanaman selada umur 10 dan 20 HST akibat velume air tertinggi dijumpai pada perlakuan $\mathrm{V}_{3}$ dengan nilai $7.01 \mathrm{~cm}$, $12.47 \mathrm{~cm}$ yang berbeda nyata dengan perlakuan $\mathrm{V}_{1}$ dan berbeda tidak nyata dengan perlakuan $\mathrm{V}_{2}$, umur 30 HST tertinggi pada perlakuan $\mathrm{V}_{3}$ dengan nilai 19.61 yang berbeda nyata dengan perlakuan lainnya. Sedangkan nilai terendah dijumpai pada perlakuan $\mathrm{V}_{1}$ dengan nilai $5.58 \mathrm{~cm}$, $8.70 \mathrm{~cm}$ dan $12.63 \mathrm{~cm}$ yang berbeda nyata dengan perlakuan lainnya.

Volume air yang sedikit menyebabkan suhu air nutrisi cepat berubah semakin panas di siang hari, sehingga membuat tanaman cepat layu dan larutan nutrisi menjadi tidak stabil sehingga menghambat tanaman dalam menyerap nutrisi yang berakibat terhadap pertumbuhan tanaman selada. Nutrisi yang mengalami suhu tinggi membuat akar tanaman sulit untuk mendapatkan oksigen sehingga tanaman tidak dapat mengambil nutrisi yang cukup dan berpengaruh terhadap pertumbuhan dan tinggi tanaman selada. suhu pada zona perakaran mempengaruhi kemampuan selada untuk menyerap unsur hara (Ginting dkk, 2010).

\section{Jumlah Daun}

Hasil analisis ragam menunjukkan bahwa, volume air berpengaruh nyata terhadap jumlah daun tanaman selada umur 10 HST dan berpengaruh sangat nyata terhadap jumlah daun tanaman selada umur 
20, dan 30 HST. Rata-rata jumlah daun tanaman selada umur 10, 20 dan 30 HST akibat volume air dapat dilihat pada Tabel 2.

Tabel 2. Rata-rata Jumlah Daun Tanaman Selada Umur 10, 20 dan 30 HST Akibat

Volume air.

\begin{tabular}{cccc}
\hline $\begin{array}{c}\text { Volume air } \\
(\mathrm{V})\end{array}$ & \multicolumn{3}{c}{$\begin{array}{c}\text { Jumlah } \\
\text { Daun }\end{array}$} \\
\cline { 2 - 4 } & $10 \mathrm{HST}$ & $20 \mathrm{HST}$ & $30 \mathrm{HST}$ \\
\hline $\mathrm{V}_{1}$ & $2.99 \mathrm{a}$ & $5.13 \mathrm{a}$ & $8.37 \mathrm{a}$ \\
$\mathrm{V}_{2}$ & $3.74 \mathrm{~b}$ & $5.56 \mathrm{~b}$ & $12.44 \mathrm{~b}$ \\
$\mathrm{~V}_{3}$ & $4.07 \mathrm{~b}$ & $7.19 \mathrm{~b}$ & $13.23 \mathrm{~b}$ \\
\hline BNJ & 1.05 & 1.00 & 1.33
\end{tabular}

Keterangan : Angka yang di ikuti huruf yang sama dalam kolom yang sama menunjukkan tidak berbeda nyata pada uji BNJ taraf 5\%.

Dari Tabel 2 dapat dijelaskan bahwa, rata-rata jumlah daun tanaman selada umur 10, 20 dan 30 HST akibat volume air yang terbanyak dijumpai pada perlakuan $\mathrm{V}_{3}$ dengan nilai 4.07, 7.19 dan 13.23 yang berbeda nyata dengan perlakuan $\mathrm{V}_{1}$ dan berbeda tidak nyata dengan perlakuan $V_{2}$. Sedangkan terendah dijumpai pada perlakuan $\mathrm{V}_{1}$ dengan nilai $2.99,5.13$ dan 8.37 yang berbeda nyata dengan perlakuan lainnya.

Hal ini diakibatkan volume air 12 dan 8 liter memberi pengaruh terhadap jumlah daun tanaman selada karena jumlah air yang banyak mempermudah akar tanaman untuk mencapai air nutrisi sehingga pertumbuhan tanaman menjadi lebih cepat serta mencegah suhu air terlalu tinggi karena dapat menggangu oksigen dalam air nutrisi. Hal ini sesuai dengan pendapat Retno (2016) menyatakan bahwa, oksigen tidak hanya diam saja di dalam air melainkan bergerak dari satu sisi kesisi yang lain, apabila suhu air semakin tinggi maka pergerakan oksigen akan semakin cepat sehingga oksigen akan terpental keluar. Hal ini akan menyebabkan proses respirasi di akar akan berkurang, energi yang dihasilkan semakin sedikit dan kemampuan untuk melakukan pertumbuhan akan berkurang.

\section{Panjang Daun}

Hasil analisis ragam menunjukkan bahwa, volume air berpengaruh sangat nyata terhadap panjang daun tanaman selada umur 10, 20, dan 30 HST. Rata-rata panjang daun tanaman selada umur 10,20 , dan 30 HST akibat volume dapat dilihat pada Tabel 3.

Tabel 3. Rata-rata Panjang Daun Tanaman Selada Umur 10, 20 dan 30 HST akibat Volume Air

\begin{tabular}{cccc}
\hline Volume air $(\mathrm{V})$ & \multicolumn{3}{c}{ Panjang Daun $(\mathrm{cm})$} \\
\cline { 2 - 4 } \cline { 2 - 3 } & $10 \mathrm{HST}$ & $20 \mathrm{HST}$ & $30 \mathrm{HST}$ \\
\hline $\mathrm{V}_{1}$ & $4.63 \mathrm{a}$ & $7.01 \mathrm{a}$ & $10.21 \mathrm{a}$ \\
$\mathrm{V}_{2}$ & $4.79 \mathrm{~b}$ & $9.91 \mathrm{~b}$ & $12.41 \mathrm{~b}$ \\
$\mathrm{~V}_{3}$ & $4.94 \mathrm{~b}$ & $10.32 \mathrm{~b}$ & $15.02 \mathrm{c}$ \\
\hline BNJ & 0.90 & 1.09 & 0.97
\end{tabular}

Keterangan : Angka yang diikuti huruf yang sama dalam kolom yang sama menunjukkan tidak berbeda nyata pada uji BNJ 5\%

Dari Tabel 3 dapat dijelaskan bahwa, rata-rata panjang daun tanaman selada umur 10, dan 20 HST akibat volume air yang terpanjang dijumpai pada perlakuan $\mathrm{V}_{3}$ dengan nilai $4.94 \mathrm{~cm}$, dan 10,32 $\mathrm{cm}$ yang berbeda nyata dengan perlakuan $\mathrm{V}_{1}$ dan tidak berbeda nyata dengan perlakuan $V_{2}$, umur 30 HST terpanjang pada perlakuan $\mathrm{V}_{3}$ dengan nilai $15.02 \mathrm{~cm}$ yang berbeda nyata dengan perlakuan lainnya. Sedangkan terpendek dijumpai pada perlakuan $\mathrm{V}_{1}$ dengan nilai $4.63 \mathrm{~cm}, 7.01 \mathrm{~cm}$ dan $10.21 \mathrm{~cm}$ yang berbeda nyata dengan perlakuan lainnya.

Panjang daun tertinggi dijumpai pada $\mathrm{V}_{3}$ dengan volume air 12 liter. Hal ini dikarenakan pada volume air 12 tanaman lebih cepat beradaptasi dan lebih cepat mencapai air nutrisi sehingga tanaman lebih cepat tumbuh. Akar tanaman yang tidak terganggu dan dapat mengambil langsung nutrisi dari air larutan nutrisi sedangkan pada volume air 4 liter akar tanaman sulit menjumpai air nutrisi secara langsung sehingga pertumbuhan akar terganggu dan menyebabkan pertumbuhan tanaman menjadi lambat. Hal ini sesuai dengan pendapat Teguh Sutanto (2015) menyatakan bahwa, akar yang kontak langsung dengan air menyerap nutrisi setiap saat, sehingga pertumbuhan tanaman lebih cepat. 


\section{Berat brangkasan basah}

Hasil analisis ragam menunjukkan bahwa, volume air berpengaruh sangat nyata terhadap berat brangkasan basah tanaman selada umur 30 HST. Rata-rata berat brangkasan basah tanaman selada umur 30 HST akibat volume air dapat dilihat pada Tabel 4.

Tabel 4. Rata-Rata Berat Tanaman Selada Umur 30 HST Akibat Volume Air

\begin{tabular}{cc}
\hline me Air (V) & $\begin{array}{c}\text { Berat Brangkasan Basah } \\
\text { (gram) }\end{array}$ \\
\cline { 2 - 2 } & $30 \mathrm{HST}$ \\
\hline $\mathrm{V}_{1}$ & $41.98 \mathrm{a}$ \\
$\mathrm{V}_{2}$ & $87.98 \mathrm{~b}$ \\
$\mathrm{~V}_{3}$ & $102.46 \mathrm{~b}$ \\
\hline BNJ & 16.46 \\
\hline
\end{tabular}

Keterangan : Angka yang diikuti huruf yang sama dalam kolom yang sama menunjukkan tidak berbeda nyata pada uji BNJ 5\%

Dari Tabel 4 dapat dijelaskan bahwa, rata-rata berat brangkasan basah tanaman selada umur 30 HST akibat volume air yang terberat pada perlakuan $\mathrm{V}_{3}$ yaitu dengan nilai 102.17 gram yang berbeda nyata dengan $\mathrm{V}_{1}$ dan berbeda tidak nyata dengan $\mathrm{V}_{2}$. Sedangkan teringan dijumpai pada perlakuan $\mathrm{V}_{1}$ dengan nilai 41.98 gram yang berbeda nyata dengan perlakuan lainnya.

Dari ketiga perlakuan terdapat hasil yang cukup terlihat dari volume air 4, 8, 12 liter. Volume air yang rendah membuat pertumbuhan selada terganggu. Volume air yang rendah menyebabkan suhu air nutrisi cepat bertambah dan akan membuat $\mathrm{pH}$ air terganggu serta membuat oksigen terlepas dari penampungan air yang menyebabkan akar tanaman kekurangan oksigen. Pernyataan ini didukung oleh pendapat Muthia Diansari (2008) dalam skripsinya yaitu temperatur yang biasa digunakan dalam budidaya hidroponik berkisar antara $28-30^{\circ}$ C. Temperatur yang tinggi akan mempengaruhi larutan nutrisi pada tendon yang mengakibatkan kadar oksigen menurun dan mengakibatkan akar kekurangan energi, suhu air yang tinggi juga dapat mengganggu jaringan membran sel akar, sehingga penyerapan nutrisi berkurang dan ini akan berpengengaruh terhadap siklus dan hasil tanaman.

\section{B. Nutrisi Good-Plant Tinggi Tanaman}

Hasil analisis ragam menunjukkan bahwa, nutrisi good-plant berpengaruh nyata terhadap tinggi tanaman selada umur 10 HST dan berpengaruh sangat nyata terhadap tinggi tanaman selada umur 20 dan 30 HST. Rata-rata tinggi tanaman selada umur 10, 20 dan 30 HST akibat nutrisi good-plant dapat dilihat pada Tabel 5.

Tabel 5. Rata-Rata Tinggi Tanaman Selada Umur 10, 20 dan 30 HST akibat nutrisi Good-plant

\begin{tabular}{|c|c|c|c|}
\hline \multirow{2}{*}{$\begin{array}{l}\text { Nutrisi Good- } \\
\text { Plant (N) }\end{array}$} & \multicolumn{3}{|c|}{ Tinggi Tanaman $(\mathrm{cm})$} \\
\hline & $10 \mathrm{HST}$ & $20 \mathrm{HST}$ & $30 \mathrm{HST}$ \\
\hline $\mathrm{N}_{1}$ & $6.10 \mathrm{a}$ & $10.14 \mathrm{a}$ & $15.48 \mathrm{a}$ \\
\hline $\mathrm{N} 2$ & $6.76 \mathrm{~b}$ & $11.57 \mathrm{~b}$ & $17.18 \mathrm{~b}$ \\
\hline N3 & $6.79 \mathrm{~b}$ & $11.62 \mathrm{~b}$ & $17.64 \mathrm{~b}$ \\
\hline BNJ & 0.72 & 1.14 & $\cdot$ \\
\hline
\end{tabular}

Keterangan : Angka yang diikuti huruf yang sama dalam kolom yang sama menunjukkan tidak berbeda nyata pada uji BNJ 5\%

Dari Tabel 5 dapat dijelaskan bahwa, rata-rata tinggi tanaman selada umur 10, 20 dan 30 HST akibat nutrisi good-plant tertinggi pada perlakuan $\mathrm{N}_{3}$ dengan nilai $6.79 \mathrm{~cm}, 11.62 \mathrm{~cm}$ dan $17.64 \mathrm{~cm}$ yang berbeda nyata dengan perlakuan $\mathrm{N}_{1}$ dan tidak berbeda nyata dengan perlakuan $\mathrm{N}_{2}$. Sedangkan nilai terendah dijumpai pada perlakuan $\mathrm{N}_{1}$ dengan nilai $6.10 \mathrm{~cm}$ dan $10.14 \mathrm{~cm} 15.48 \mathrm{~cm}$ yang berbeda nyata dengan perlakuan lainnya.

Tingginya nutrisi pada perlakuan $\mathrm{N}_{3}$ berpengaruh sangat nyata terhadap pertumbuhan tanaman selada. kepekatan nutrisi 1000 ppm yang tidak jauh dari rokomendasinya yaitu $800 \mathrm{ppm}$. Karena semakin tinggi kepekatan semakin besar juga unsur yang terkandung di dalamnya sehinga mencukupi kebutuhan hara bagi tanaman. Tingginya nitrogen pada nutrisi tanaman akan mempengaruhi pada pertumbuhan vegetatif tanaman yang 
ditunjukkan dengan pemanjangan batang (Harvani, dkk. 2014). Nutrisi yang diberikan sebaikknya di sesuaikan dengan umur tanaman. Menurut pendapat Karsono (2002) menyatakan bahwa, jumlah hara yang dibutuhkan tanaman fase vegetatif dan fase generatif berbeda sehingga kebutuhan unsur hara pada tanaman meningkat seiring dengan pertumbuhannya. Kepekatan larutan nutrisi sebaiknya ditingkatkan seiring dengan pertumbuhan tanaman. Namun jika kepekatannya terlalu tinggi maka efisiensi penyerapan hara oleh akar menurun karena jenuh dalam menyerap.

\section{Jumlah Daun}

Hasil analisis ragam menunjukkan bahwa, nutrisi good-plant berpengaruh tidak nyata terhadap jumlah daun tanaman selada umur 10 dan $20 \mathrm{HST}$, tetapi berpengaruh sangat nyata terhadap jumlah daun tanaman selada umur 30 HST. Rata-rata jumlah daun tanaman selada umur 10, 20 dan 30 HST akibat nutrisi good-plant dapat dilihat pada Tabel 6.

Tabel 6. Rata-Rata Jumlah Daun Tanaman Selada Umur 10, 20 dan 30 HST akibat Nutrisi Good-Plant

\begin{tabular}{|c|c|c|c|}
\hline \multirow{2}{*}{$\begin{array}{l}\text { Nutrisi Good- } \\
\text { Plant(N) }\end{array}$} & \multicolumn{3}{|c|}{ Jumlah Daun } \\
\hline & 10 HST & $20 \mathrm{HST}$ & $\begin{array}{c}30 \\
\text { HST }\end{array}$ \\
\hline$\overline{N_{1}}$ & $3.16 \mathrm{a}$ & $5.83 \mathrm{a}$ & $10.06 \mathrm{a}$ \\
\hline $\mathrm{N}_{2}$ & $3.73 \mathrm{~b}$ & $6.49 \mathrm{~b}$ & $11.58 \mathrm{~b}$ \\
\hline $\mathrm{N}_{3}$ & $3.71 \mathrm{~b}$ & $6.56 \mathrm{~b}$ & $12.41 \mathrm{~b}$ \\
\hline $\mathrm{BNJ}$ & 1.05 & 1.00 & 1.33 \\
\hline
\end{tabular}

Keterangan : Angka yang diikuti huruf yang sama dalam kolom yang sama menunjukkan tidak berbeda nyata pada uji BNJ 5\%

Dari Tabel 6 dapat dijelaskan bahwa, rata-rata jumlah daun tanaman selada umur 10 HST akibat nutrisi good-plant terbanyak dijumpai pada perlakuan $\mathrm{N}_{2}$ dengan nilai 3.73 yang berbeda nyata dengan perlakuan $\mathrm{N}_{1}$ dan berbeda tidak nyata dengan perlakuan $\mathrm{N}_{2}$, umur 20 dan $30 \mathrm{HST}$ tertinggi dijumpai pada perlakuan $\mathrm{N}_{3}$ dengan nilai 6.56 dan 12.41 yang berbeda nyata dengan perlakuan $\mathrm{N}_{1}$ dan tidak berbeda nyata dengan perlakuan $\mathrm{N}_{3}$. Sedangkan nilai terendah dijumpai pada perlakuan $\mathrm{N}_{1}$ yaitu dengan nilai 3.16, 5.83 dan 10.06 yang berbeda nyata dengan perlakuan lainnya.

Dari hasil pengamatan jumlah daun tertinggi dijumpai pada perlakuan $\mathrm{N}_{3}$ yaitu 1000 ppm, tingginya kadar nutrisi membuat membuat tanaman lebih cepat berkembang. Besarnya rasio amonium dalam nutrisi hidroponik menjadi penunjang tanaman untuk mempercepat pertumbuhan daun. Sesuai dengan pendapat Wendiatnova (2013) mengemukakan bahwa, rasio amonium yang lebih besar membuat sel-sel raksasa sehingga tanaman tumbuh lebih cepat dan lebih besar. Daun yang terbentuk lebar dan evapotrasnpirasinya lebih besar sehingga daya serap air dan hara meningkat, hanya saja daun mudah layu. Pertumbuhan vegetatif yang terpacu menghasilkan banyak daun dengan ukuran yang lebar, akan tetapi akibat dari tingginya nutrisi berdampak pada warna daun selada yang tidak berwarna hijau muda namun warna daun tampak lebih gelap dan rimbun. Pernyataan ini didukung dengan pendapat Pertiwi (2016) menyatakan bahwa, apabila tanaman kelebihan unsur nitrogen maka daun tanaman akan terlihat lebih hujau dan tanaman rimbun dengan daun.

\section{Panjang Daun}

Hasil analisis ragam menunjukkan bahwa, nutrisi good-plant berpengaruh tidak nyata terhadap panjang daun tanaman selada umur $10 \mathrm{HST}$, berpengaruh nyata $20 \mathrm{HST}$, berpengaruh sangat nyata umur 30 HST. Rata-rata panjang daun tanaman selada umur 10, 20, dan 30 HST akibat nutrisi good-plant dapat dilihat pada Tabel 7.

Tabel 7. Rata-Rata Penjang Daun Tanaman Selada Umur 10, 20 dan 30 HST Akibat Nutrisi Good-Plant

\begin{tabular}{cccc}
\hline \multirow{2}{*}{$\begin{array}{c}\text { Nutrisi Good- } \\
\text { Plant (N) }\end{array}$} & \multicolumn{3}{c}{ Panjang Daun $(\mathrm{cm})$} \\
\cline { 2 - 3 } & $10 \mathrm{HST}$ & $20 \mathrm{HST}$ & 30 HST \\
\hline $\mathrm{N}_{1}$ & $4.11 \mathrm{a}$ & $8.28 \mathrm{a}$ & $11.57 \mathrm{a}$ \\
$\mathrm{N}_{2}$ & $4.66 \mathrm{~b}$ & $9.29 \mathrm{~b}$ & $12.91 \mathrm{~b}$ \\
$\mathrm{~N}_{3}$ & $4.70 \mathrm{~b}$ & $9.68 \mathrm{~b}$ & $13.16 \mathrm{~b}$ \\
\hline BNJ & 0.90 & 1.09 & 0.97 \\
\hline
\end{tabular}

Keterangan : Angka yang diikuti huruf yang sama dalam kolom yang sama menunjukkan tidak berbeda nyata pada uji BNJ 5\% 
Dari Tabel 7 dapat dijelaskan bahwa, rata-rata panjang daun tanaman selada umur 10, 20 dan 30 HST akibat nutrisi good-plant terpanjang dijumpai pada perlakuan $\mathrm{N}_{3}$ dengan nilai $4.70 \mathrm{~cm}, 9.68 \mathrm{~cm}$ dan $13.16 \mathrm{~cm}$ yang yang berbeda nyata dengan perlakuan $\mathrm{N}_{1}$ dan tidak bebeda nyata dengan perlakuan $\mathrm{N}_{2}$. Sedangkan terpendek dijumpai pada perlakuan $\mathrm{N}_{1}$ dengan nilai $4.11 \mathrm{~cm}, 8.28$ dan $11.57 \mathrm{~cm}$ yang berbeda nyata dengan perlakuan lainnya.

Tingginya nitrogen sangat mengantungkan bagi tanaman daun karena dapat memacu pertumbuhan daun dan batang (Lingga. P, 2005). Pupuk good-plant sangat cocok untuk tanaman sayuran batang dan daun karena mengandung nitrogen lebih tinggi dari pupuk premium lain yang berfungsi untuk memacu pertumbuhan pada fase vegetatif terutama daun dan batang (harvani, dkk. 2014).

\section{Berat Brangkasan Basah}

Hasil analisis ragam menunjukkan bahwa, nutrisi good-plant berpengaruh nyata terhadap berat brangkasan basah tanaman selada umur 30 HST. Rata-rata berat brangkasan basah tanaman selada umur 30 HST akibat nutrisi good-plant dapat dilihat pada Tabel 8.

Tabel 8. Rata-Rata Berat Tanaman Selada Umur 30 HST Akibat Nutrisi Good-Plant

\begin{tabular}{cc}
\hline Nutrisi Good-Plant (N) & $\begin{array}{c}\text { Berat Brangkasan Basah } \\
(\text { gram) }\end{array}$ \\
\cline { 2 - 2 } & $30 \mathrm{HST}$ \\
\hline $\mathrm{N}_{1}$ & $67.18 \mathrm{a}$ \\
$\mathrm{N}_{2}$ & $80.74 \mathrm{~b}$ \\
$\mathrm{~N}_{3}$ & $84.20 \mathrm{~b}$ \\
\hline $\mathrm{BNJ}$ & 16.46 \\
\hline
\end{tabular}

Keterangan : Angka yang diikiti huruf yang sama dalam kolom yang sama menunjukkan tidak berbeda nyata pada uji BNJ 5\%

Dari Tabel 8 dapat dijelaskan bahwa, rata-rata berat brangkasan basah tanaman selada umur 30 HST akibat nutrisi goodplant terberat dijumpai pada perlakuan $\mathrm{N}_{3}$ dengan nilai 84.20 gram yang berbeda nyata dengan perlakuan $\mathrm{N}_{1}$ dan tidak berbeda nyata dengan perlakuan $\mathrm{N}_{2}$. Sedangkan teringan dijumpai pada perlakuan $\mathrm{N}_{1}$ dengan nilai 67.18 gram yang berbeda nyata dengan perlakuan lainnya.

Tingginya kandungan nitrogen dan amonium dalam nutrisi goodplant pada perlakuan $\mathrm{N}_{3}$ membuat tanaman menjadi labih cepat tumbuh dan tumbuh dengan pesat. Amonium menyebabkan tanaman tumbuh dengan pesat sel-sel tanaman menjadi cepat membesar dan tahan terhadap hama penyakit tanaman. Sementara tanaman yang kekurangan nitrogen pertumbuhannya terhambat (Harvani, dkk. 2014).

\section{Pengaruh Interaksi Volume Air dan Nutrisi Good-Plant}

Hasil analisis ragam menunjukkan bahwa, tidak terdapat interaksi yang nyata antara volume air dan nutrisi good-plant terhadap semua parameter yang diamati.

\section{PENUTUP}

\section{Kesimpulan}

1. Volume air berpengaruh sangat nyata terhadap tinggi tanaman dan panjang daun umur 10, 20 dan 30 HST, jumlah daun umur 20 dan 30 HST, berat brangkasan basah umur 30 HST, berpengaruh nyata terhadap jumlah daun umur 10 HST.

2. Nutrisi good-plant berpengaruh sangat nyata terhadap tinggi tanaman umur 20 dan $30 \mathrm{HST}$, jumlah daun dan panjang daun umur $30 \mathrm{HST}$, berpengaruh nyata terhadap tinggi tanaman umur $10 \mathrm{HST}$, panjang daun umur 20 HST, berat brangkasan basah umur 30 HST.

3. Tidak terdapat interaksi antara volume air dan nutrisi good-plant terdadap semua perlakuan.

\section{DAFTAR PUSTAKA}

Ginting, C. dkk. 2010. Kajian biologis tanaman selada lactuca sativa. L dalam berbaga kondisi lingkungan pada sistem hidroponik. Agroteknologi fakultas pertanian universitas Halu oleo. Kendari. 
Pratiwi, Y. 2016. Makalah hidroponik. Allriserulia.blogspot.co,id.

Lingga, P. 2005. Bercocok tanam tampa tanah. Penebar swadaya, Jakarta.

Mas' ud. H. 2009. System hidroponik dengan nutrisi dan media tanam berbeda terhadap pertumbuhan dan hasil selada. november. 2016. jurnal. untad. ac. id. 2012. Html.

Prihmantoro, heru. 2005. Hidroponik sayuran semusim untuk bisnis dan hobi. penebar swadaya, Jakarta.

Wendiatnova. 2013. Nutrisi hidroponik. Wendiatnova.blogspot.com. di akses 16 juni 2017.

Karsono, S. dkk. 2002. Hidroponik skala rumah tangga. Agromedia pustaka Indonesia.

Harvani, D.dkk. 2014. Pengaruh pengunaan nutrisi tanaman dengan menggunakan media yang berbeda pada tanaman pakchoi (brassica juncea L.) hidroponik. Himatan faperta unpad.

Retno. 2016 -Suhu dan kelembabab suhu dan oksigen”. http://tani.box.com.2016. Di akses 18 september 2018. 